\title{
Māori in Video Games - A Digital Identity
}

\section{A 'digital identity' emerges}

Like an organism, identity evolves, it is in a constant state of flux, and as it comes into contact with another element its form is changed. Māori identity is no different. The decision to leave the islands of the Northern and Eastern regions of the Pacific was the first element to contribute to NZ Māori identity. This migration, which lead Māori ancestors to Aotearoa caused a change in language and a change in culture. No longer did we hula, now we haka and our clothes changed to suit the colder seasons.

The next evolution in Māori identity came with the arrival of Captain James Cook and the influx of European settlers. Like all Indigenous peoples, contact with white colonials saw the most outrageous threats to Māori identity. The migration of Māori to Aotearoa/New Zealand added to their identity structure, but had no real effect on Māori world view. The arrival of colonials saw the introduction of an entirely new world view, with a completely different way of knowing. This collision of two worlds would forever change Māori identity. As Māori fought to hold on to their sense of being, the Pākehā, the Haole, the Papa'a, the White world continued to consume all in its path. Words like 'dominate' and 'assimilate' were products of this collision of worlds. However, through this struggle, Māori showed tremendous resilience, and this spirit was evident when Rewi Maniapoto, the Ngāti Maniapoto chief, cried out the words, 'ka whawhai tonu mātou, ake, ake, ake' 'we will never relent, we will never concede'. ${ }^{1}$ In this spirit, Māori proved that we are not adverse to change, we looked at

\footnotetext{
$1 \quad$ K. Te Kanawa, personal communication, 2012.
}

Dean Mahuta is a Lecturer in Te Ara Poutama - The Faculty of Māori Development and a Researcher in Te Ipukarea - The National Māori Language Institute at AUT University. 
ways to integrate aspects of a new world into our own, so that, Māori identity continued to grow, to develop, to evolve. While one world sought to extinguish, the 'other', as often defined by post-colonial theory, sought to enrich.

It is in this way that Māori have kept their culture alive, incorporating new elements into traditional Māori ways of knowing. Therefore, with the emergence of digital technology, a new collision of worlds is happening. In an age of globalisation, Māori are looking at ways of interacting with digital technology. The digital spaces created are impacting on the way the world views indigenous cultures. The speed and openaccess of information is amazing, not that long ago, the worlds idea of indigenous peoples came from the exploits of white explorers, written and published through a euro-centric lens, defining, interpreting, through a world view ill equipped to understand the complexities of indigenous ways of knowing. Today, we as Māori, we as Indigenous peoples now have a chance to occupy these spaces, moreover, the digital space is becoming the arena of globalisation, through interaction, a Māori digital identity is emerging. Digital spaces are created every day and Māori are able to contribute to the development of this emerging identity, because, as Mills states, the "... digital, has the potential to create and nurture a distinctive 'public space' for the articulation of alternative Māori worldviews."2

\section{Natives in gaming}

One particular digital space that Māori must start occupying, is that created by video games.

In the United States, the indigenous image has been a common occurrence in the search for playable characters and races, often being cast as the barbaric warrior that the white hero must defeat/overcome. If Native American peoples are cast on the side of good, then it is normally in the role of a servant, the "native" partner with local knowledge, but always subordinate to the civilised, "white" hero, who is the main protagonist. In some games, the white hero eventually learns

M. Mills, 'Pou Rewa: The Liquid Post, Maori Go Digital?' in Third Text, Vol. 23, Issue 3. May. London: Routledge, 2009. 
that he has native ancestry and becomes the stereotypical "half-breed hero". ${ }^{3}$

During the remainder of the game, the player comes to terms with this new sense of identity, often awakening latent mystical powers that are attuned to nature. These powers are stereotypical of many games that include Native American characters, such as heightened senses, the ability to commune with spirits, and in some cases, using totems with specific powers, that increase character stats such as strength, speed, dexterity. 4 In the popular fighting game, Mortal Kombat, players can choose the character, Nighthawk, who is a Native American, wielding twin tomahawks, complete with face paint and the ability to call a spirit wolf.

The most disturbing game I have come across is called 'Custer's Revenge', a game developed for the Atari 2600, back in 1980s. In this game the user plays an aroused General Custer, and the aim of the game is to dodge enemy arrows as you make your way towards an "Indian princess" that is tied to a post - To indicate that your character has achieved his goal, the 'Custer' character proceeds to rape the "indian princess'. Thus, the rape of the Native woman is the prize. Due to the outcry from the Native American community, this title was removed from shelves. ${ }^{5}$ This game is definitely the extreme in terms of native misrepresentation in video games.

\section{Māori in gaming}

The use of Māori imagery in the video game industry is fairly limited, though the Māori motif has been used internationally in Media, sports and advertising for a long time. The most internationally renowned Māori image used is the haka, or the Māori posture dance, made particularly famous by the All Blacks, New Zealand's National Rugby team.

The most recent example of the 'commodification' of Māori culture and imagery was in the 2006 Fiat car television advertisement in Italy. The ad showed women performing a

3 B. A. Dillon. Native representations in video games. Retrieved on 10/02/12 from http://vimeo.com/25991603

4 Project COE. Native Americans in Video Games: Racism, Stereotypes, \& The Digitized Indian. Retrieved on $10 / 02 / 12$ from http://www.projectcoe.com/2011/04/04/native-americans-in-videogames-racism-stereotypes-and-progress/

5 B. A. Dillon. Native representations in video games. Retrieved on 10/02/12 from http://vimeo.com/25991603 
bastardised form of the haka known as 'ka mate'. Although several attempts were made by Derek Lardelli, a Māori performing arts expert, to rectify this issue by offering his services as a composer to create a haka relevant to their needs, Fiat ignored him. According to Derek Lardelli, it is "completely inappropriate to misuse cultural icons and symbolism in the manner that Fiat have. They [Fiat] had the opportunity to engage on a culturally appropriate level but chose to ignore this."6

\section{The Mark of Kri}

The Sony Playstation 2 game, 'The Mark of Kri,' has also misrepresented Maori. In this game, the user controls a character called Rau, a noble warrior called to adventure to save the world from the darkness. Your adventures send you in pursuit of a collection of 'marks', that you must obtain before your enemies, because if combined, the seal created will unleash a dark force that will destroy all life. Already, we begin to see some common aspects attributed to games that use indigenous themes, the use of markings that control 'dark' magic for example. However, the problems don't end there, it is usually apparent in the art style and direction of the game. 'The Mark of Kri', is obviously inspired by Māori and Polynesian culture. If we take the time to look at the main character, Rau, he has a very Māori, South Pacific physical appearance, from body build, to facial features, to the tattoos over his face and body, and finally his hair, which is tied in a topknot, a typical hairstyle of Māori.

The title of the game itself also points to a 'Māori' image, 'mark', refers to the symbol Rau is charged with collecting, the actual design of these marks is heavily inspired by 'tā moko', the traditional Māori art of tattooing.

The combat system of the game is straight forward, meaning, the character has the ability, and is proficient in a number of weapons, from a double axe, to a sword and a bow and arrow. Where it gets interesting is when Rau unlocks the use of a wooden spear-like weapon. In the game, Rau receives this spear from a nature spirit, after he saves a particularly ancient

$6 \quad$ NZPA. 'Italians drive ahead with Car Mate haka [video clip]', in The NZ Herald, July 4. Retrieved on 16/11/2011 from http://www.nzherald.co.nz/nz/news/article.cfm?c_id=1\&objectid=1038961 $\underline{9}$ 
tree. Rau is then directed to a training area to allow the player to learn the combat moves associated with it. This unique weapon is called a taiaha, and it is a Māori weapon. In Māori society, the taiaha is considered by some to be the most illustrious of Māori weaponry. Spear weapons are common throughout Polynesia in many forms, but the taiaha is only found in Aotearoa/New Zealand. The top has a wide blade edge used to split and slice. As you move down the body of the taiaha it rounds off and at the bottom is the head, completely carved with the tip protruding like a tongue, adorned with elaborately carved designs.

The character names also point to a Māori and Pacific background, names like Mauruku and Tati. The "native" deity within the game has the name, Rongo, and is a nature spirit. This also is derived from the Māori world, as Rongo is from the pantheon of Māori gods.

It is obvious that San Diego Studios did research, for how could they have created such Māori characters, weapons and lore. However, like many non-indigenous people they did not include context, language, meaning, and ways of knowing. Jeff Merghat, lead designer for the game, says, that Mark of Kri is not a Māori game, because Rau is not Māori, his tattoos are not Māori, stating that;

"...Everyone liked the Polynesian flavour that the game was taking on, so we tried to make things with a more contemporary or inventive Polynesian twist where we could. Like Rau's chin tattoo. In New Zealand Women are the ones who traditionally wear a tattoo on their chin. But Rau's isn't Maori and he's not from or in New Zealand, so we kind of keep our ass covered that way. We apologize for any coincidences."7

Merghat's argument, saying that by taking a moko that is meant for women and putting it on a man, makes it nonMāori, is ignorant and lacks cultural sensitivity and ethics. Therefore, it is obvious that we cannot wait for the white man to do the right thing, we as Māori, we as indigenous peoples, must get involved with the creation process, we must now take the next step beyond protest, we must be active participants.

'Interview with Jeff Merghart. The Mark of Kri's art designer talks about inspiration, hand animation and more.' July 18. Retrieved on 05/11/2011 from http://ps2.ign.com/articles/365/365290p1.html 


\section{Brink}

More recent is the game Brink, created by Bethesda for the Playstation 3. This game stages gun fights between two sides vying for control over living areas and city zones. It is based in a post-apocalyptic society, where the world has been flooded and the survivors have banded together creating a floating metropolis that has, over the years, degraded as resources start running out.

Māori images appear in this game, in the character creation process, where the player creates a character that will then choose a side to fight for. In the customization process, the character can be adorned with different types of tattoos, one option is the Māori tā moko design. However, it is not called tā moko, nor does it appear under the category of "tribal" tattoo as many games have done in the past, rather, they use the term 'kirituhi'. The use of this term shows me as a Māori gamer, that this development team have done their research. Kirituhi is the term used by Māori tattoo artists for the art form, particularly when tatooing someone who isn't Māori. Kirituhi is without meaning, it is without whakapapa, or geneology, it is not tā moko, but is body art. Therefore, Bethesda as game developers have covered themselves culturally because they took the time to look for a culturally appropriate form of Māori tā moko. This is an example of what can happen when developers put time into proper research.

\section{Māori Companies}

Today, with the ease of access to digital technology, indigenous peoples can start to claim digital spaces that have been around since digital gaming first arose in consoles and computers in the early 1970s. We must claim these spaces, and begin to inform these spaces with culturally appropriate indigenous ways of knowing. Maree Mills, explains how kaupapa Māori, or, a Māori way of knowing can inform those things we create as indigenous peoples, stating, "It is characteristic of kaupapa Māori to combine thinking with doing and making, and to consider from the start who the knowledge or the art you make is for."8

M. Mills, 'Pou Rewa: The Liquid Post, Maori Go Digital?' in Third Text, Vol. 23, Issue 3. May. London: Routledge, 2009. 
Based on this, the following are examples of what Māori are doing to inhabit this particular digital space.

\section{Ignite Studios}

The lead designer and founder of Ignite Studios is Kingi Gilbert of Te Arawa descent who has worked in the gaming and digital entertainment industry for many years. His most recent work was as a mediator between Ngāti Toa and Sidhe Interative, New Zealand's leading game development company. The popular haka, ka mate, was composed by the Ngāti Toa chief, Te Rauparaha, and so Sidhe Interactive approached Kingi to facility discussions between themselves and the tribe over proper portrayal of the haka. Including the motion capture of iwi members performing the haka, which was used in the game.

Kingi also wrote to Sony regarding Mark of Kri, expressing his concerns about the misrepresentation of Māori culture, with specific reference to the use of the taiaha within the game. Saying that Māori go through a rigorous training process in order to become experts in the use of taiaha, which is not emulated in the game.

\section{Metia Interactive}

The founder of Metia Interactive is Maru Nihoniho. Metia Interactive won a World Summit Award in 2011 for their game Sparx developed in conjunction with the University of Auckland's Faculty of Medical and Health sciences. It is a game developed for an e-therapy initiative partially funded my New Zealand's Ministry of Health. According to Metia's website:

"SPARX takes the form of an animated 3D game where users learn real-life skills by solving challenges to rid a fantasy world from gloom and negativity. Culturallyrelevant elements have been incorporated into the game world to ensure the programme has wide cultural acceptability." 9

Metia Interactive. SPARX wins at the World Summit Awards 2011.

Retrieved 23/04/2012 from http://www.metia.co.nz/news.html 
The Guardian, is Metia's current project and when completed it will be the first Māori themed video game for consoles. The game centers on a Māori female warrior, an expert in Māori custom and weaponry, she is charged with becoming a guardian of her people and of the environment.

\section{Conclusion}

These two Māori owned companies are examples of Māori becoming more involved in the process and informing digital spaces with appropriate cultural knowledge and epistemologies. It is important that we are proactive in occupying digital spaces to ensure that we retain a certain amount of control over how our knowledge and images are used, and how our digital identity is formed.

\section{Bibliography}

Brown, D. 2007. 'Te Ahua Hiko: Digital Cultural Heritage and Indigenous Objects, People, and Environments' in Cameron, F. And Kenderdine, S. (Ed). Theorizing Digital Cultural Heritage: A Critical Discourse. Cambridge: MIT Press. (pp. 77-92).

Diamandaki, K. 2003. 'Virtual ethnicity and digital diasporas: Identity construction in cyberspace.' Global Media Journal. Vol.2. Issue 2. Retrieved 24/03/12 from http://lass.purduecal.edu/cca/gmj/sp03/graduatesp03/gmjsp03grad-diamandaki.htm

Dillon, B. A. 2011. 'Native representation in video games.' Retrieved on 10/02/12 from http://vimeo.com/25991603

Engels-Shwarzpaul, T. 2005. 'Dislocating William and Rau: The Wild Man in Virtual Worlds.' Retrieved on 15/11/2011 from http://www.ngaaho.maori.nz/project.php?project_id=110\&m=29

IGN. 2002. 'Interview with Jeff Merghart. The Mark of Kri's art designer talks about inspiration, hand animation and more.' July 18. Retrieved on 05/11/2011 from http://ps2.ign.com/articles/365/365290p1.html

Mills, M. 2009. 'Pou Rewa: The Liquid Post, Maori Go Digital?' in Third Text, Vol. 23, Issue 3. May. London: Routledge. (pp. 241-250).

NZPA. 2006. 'Italians drive ahead with Car Mate haka [video clip]', in The NZ Herald, July 4. Retrieved on 16/11/2011 from http://www.nzherald.co.nz/nz/news/article.cfm?c id=1\&objectid $=10389619$

Project COE. 2011. 'Native Americans in Video Games: Racism, Stereotypes, \& The Digitized Indian.' Retrieved on 10/02/12 from http://www.projectcoe.com/2011/04/04/native-americans-invideo-games-racism-stereotypes-and-progress/ 
Te Kanawa, K. 2012. Personal communication. Māori and Pasifika Postgraduate Wānanga, May.

Metia Interactive News. 'SPARX wins at theWorld Summit Awards 2011,

Retrieved $23 / 11 / 2011$

from

http://www.metia.co.nz/news.html 